\title{
Toplumsal Eleștiri Yöntemi Olarak Mizah ve Türk Mizahı: Yeni Medyadan Bahattin Örneği
}

\author{
Ufuk Boz'
}

\author{
Öz
}

Mizah, diğer insani zevkler gibi toplumsal bir olgudur. İnsanın sosyal hayatında değişmez, yıkılmaz ve kader gibi gösterilen olgulara karşı bir özgürleşme çabasıdır. Mizah, tarih boyunca genellikle eleştiri ve muhalefet yanlı tavrını ortaya koymuş ve bu nedenle mevcut iktidarlar tarafından denetim altına alınmak istenmiştir. Mizah ilk çağlardan itibaren var olmakla birlikte, içinde bulunduğu döneme, topluma, kültüre ve teknolojiye göre değişiklik gösterir. Illk değişiklik sözlü mizahtan yazılı mizaha geçerken yaşanmıştır. Daha sonra ise bu süreci matbaa, fotoğraf makinesi, sinema, televizyon ve yeni medyanın gelişimiyle gelen köklü değişimler izlemiştir. 1990 'ların ikinci yarısından itibaren internet tüm dünyada olduğu gibi Türkiye'de de yayılmaya başlamıştır. İnternetle birlikte oluşan yeni medyada, daha önce geleneksel medyada da var olan mizah türleri bazı değişikliklere uğramıştır. Dijital yani 0-1 tabanına indirgendiğinde sayısal hale getirilen her türlü işitsel, görsel, yazılı içeriğin yeni medyada yer alması ve kolaylıkla aktarılması, geleneksel medyanın içerdiği yazılı, görsel ve sözel mizahın yeniden aktarılmasını sağladığı gibi, manipüle edilmiş fotoğraflara benzer şekilde bazı yeni iletişim formatlarının ortaya çıkmasına da neden olmuştur. Geleneksel medyada çok yoğun olarak kullanılan fotoğraflar, yeni medyada da yaygın olmakla birlikte bazı değişimler geçirmiştir. Bu konuda verilebilecek en güzel örneklerden biri de, Türkiye'de sosyal medyada bir fenomene dönüşen Uykusuz dergisinin Bahattin adlı karakteridir.

Çalışmada genel anlamda mizah toplumsal eleştiri yöntemi olarak ele alındıktan sonra Türk mizahının tarihten günümüze ulaşma biçimine değinilmek istenmekte ve en son günümüz mizahının ilginç bir formu olanBahattin karakterinin yeni medyada, sosyal medyada ve yazılı basında işlenme, değerlendirilme ve yorumlanma biçimiincelenmek istenmektedir.

Çalışmanın ilk üç bölümü teorik literatür taramasına dayanmakta, son bölümün verilerini, Bahattin konusundaki diyaloglar, tartışmalar, eleştiri yazıları ve haberler oluşturmaktadır. Yöntem olarak literatür taramasının yanında niteliksel araştırmanın içerik analizi,yorumlama ve söylem analizi şeklinde karma bir yöntem kullanılmıştır. Veriler Mart 2013 ve Nisan 2014 tarihleri arasında Google arama motorunda, Türkçe "Bahattin" kelimesi yazılarak tarama yapılması sonucunda konunun geçtiği haber sitelerinden, Ekşi Sözlük'ten, gündelik gazetelerin internet portallerinden, Facebook ve Twitter gibi yaygın sosyal medyadan ve ayrıca Bahattin konusunda yayın yapan sitelerdenelde edilmiştir. Verilerin seçimi konusunda rastgele örneklem seçimi yöntemi kullanılmıştır. Son bölüm, ulaşılan sonuçlara ayrılmıştır.

Sonuç olarak denilebilir ki, mizahın insanlık tarihi boyunca sürdürdüğü toplumsal eleştiri işlevi günümüzde de sürmekte, günümüzde buna internetin etkisi ile, etkileşim, katılım, hızııık, kolay çoğalma, kolay yayılma gibi çok sayıda özellik eklenmekte, bu süreçte yerelin devreye girmesi ile dil ve söylem önemli değişimler geçirmekte, mizah teknolojik dönüşümlerle harmanlanarak varlığını sürdürmektedir. Ve bu süreç en tutarlı olarak ancak indirgemeci olmayan çoklu bakış 
açıları ile doğru bir şekilde değerlendirilebilir. Bu çalışmanın son kısmında irdelenen Türkiye'de Bahattin karakterinin etrafında oluşan karmaşık süreç bunun tipik bir örneğidir.

Anahtar Kelimeler: Mizah, Türk Mizahı, Yeni Medya, Sosyal Medya, Bahattin.

\title{
Humor As a Method of Social Criticism and Turkish Humor: The Bahattin Example of New Media
}

\begin{abstract}
IHumoris the social phenomenon like human pleasures. Humor is a liberation effort against the cases that is presented as constant, indestructible and faith in the social life of human. Humor has often revealed its attitude supporting the criticism and opposition throughout the history. Therefore, it is demanded to be taken under control by the present governments. Humor from the early ages, however it changes and develops depending on the period, society, culture and technology. The first changes of humor was experienced in passing from verbal humor to written one. Later on, the development of new radical changes related to printing press, camera, film, television and new media followed this process. The internet began growing up in Turkey in second half of the 90's as in all around the world. Existing types of humor in traditional media has undergone some changes and formed new media with the internet. New media in the digital means when reduced to the base 0-1; every each digitized auditory, visual and written content take place in the new media and are easily transferred. In this manner, written, visual and verbal humor contained in the traditional media are retransferred to the new media and public, and it has led to the development and show up of the new communication formats likewise the manipulated photos in this new media. The photographs used very extensively in traditional media also have been used in a common manner in new media but they have undergone some changes. The character called as "Bahattin" of "Uykusuz" Magazine, which became a phenomenon in social media, can be shown as one of the best examples.
\end{abstract}

In the present study, after the tackling of humor as a social criticism in the general sense, it is sought to touch upon, how Turkish humor reached its present day, and to examine how the character of Bahattin, an interesting form of contemporary humor, is dealt, evaluated and interpreted in new media, social media and printed press.

The initial three parts of the study is based on theoretical literature review, while the data of the last part consists of dialogues, discussions, reviews and news concerning Bahattin. A mixed method is used in the study, consisting of content analysis of the qualitative research, interpretation and discourse analysis, in addition to literature review. The data were obtained, from news websites, Ekşi Sözlük, internet portals of daily newspapers and popular media such as Facebook and Twitter, in consequence of the searches conducted via the Google search engine between March 2013 and April 2014, and also from the websites publishing materials on Bahattin. Random sample selection method is used with regards to data selection. The final part is dedicated to the results reached.

In conclusion, it is possible to state, the social criticism function of humor, which has lasted throughout the history of humanity still goes on, and, with the impact of internet, nowadays gains many characteristics like interaction, participation, speed, easy reproduction, easy spread, etc., 
within this process, with the local coming into play, language and discourse go through significant changes, and humor carries on, through being blended with technological transformations. The relevant process may be evaluated in the most consistent manner through non-reductive multiple perspectives. The complex process emerging around the character of Bahattin in Turkey, as thoroughly examined in the final part of the present study, is a typical example of this.

Keywords: Humor,Turkish Humor, New Media, Social Media, Bahattin. 
sözlükte gülmece, "eğlendirme, güldürme ve bir kimsenin davranışlarına incitmeden takılma amacını güden ince alay, mizah, humor" olarak tanımlanmıştır (http://www.tdk.gov.tr/index. php?option). İngilizce Sözlükte humor (humour), "mizah, güldürü, espri, başkalarını güldürebilme yeteneği” olarak tanımlanmıştır (Kurt, 2011: 231). Batı kültüründe "humour" olarak geçen mizah toplumsal işlevi ile değerlendirilmekte, güldürürken sorgulamayı hatta yıkıcılığı içermektedir. Mizahın kavramsal boyutuyla birlikte ele alınması, tanımların sınıflandırımasıyla ilgili birtakım sorunları da beraberinde getirmektedir (Avcı, 2003). Mizah üzerine yapılan tanımların kısıtlılığı, genel anlamda bir tanımın yapılamadığını göstermektedir. Mizahın karmaşık bir kavram olması, sınıflandırılmasını zorlaştırmaktadır.

Mizah, ortaya çıktığı tarihten bu yana öncelikli görevi olan eğlendirme, hoşça vakit geçirme, olayların tüm ciddiyetine karşın bulabildiği tüm "komik" noktaları gözler önüne serme gibi asli görevini yerine getirmesinin yanında toplum içerisinde yönetici konumda bulunan lider, soy, tarikat, meclis, zümre, topluluk vb. pek çok kişi ve kurumu kimi zaman destekleme ancak çoğunlukla muhalefet ve hicvetme görevini de yerine getirmiştir. Mizah, İsa'dan önceki yüzyıllardan beri, insanoğlunun bir yandan kabullenip içinde yaşamaya çalıştığı, bir yandan da değiştirmeye çaba gösterdiği toplumsal hayatına ve bu verili toplumsal hayatını, konumunu ona değişmez bir kader gibi göstermeye yönelik gelenek, töreler ve bağnaz düşüncelere karşı bir özgürleşme çabası olmuştur. Ciddi olanın, gücüne erişilmez olan iktidar sahiplerinin, onlara dayanak olan dar görüşlülüğün, bağnazca davranışların gülünçleştirilmesi, reel hayatın karşısında tek tek kaldıkları sürece boyun eğen sıradan insanların, topluca yüreklenme, nefes alma, bir çözüm arama çabası olmuştur (Oskay, 2000: 25). Mizah, iktidarın ince dokulu ağını ters-yüz edebilir, bu ağı birden görünür kılabilir, ama iktidarı katışıksız bir vahşiliğe de dönüştürebilir. Çünkü iktidarın son noktada mizaha karşı söyleyebileceği hiçbir şey yoktur (Sanders, 2001: 45). Mizah yapabilme yeteneği olan bir insan, kendisini kısıtlayan hükümet tarafından bile tamamıyla baskı altında tutulamaz. Çünkü bu yeteneğe sahip olan bir insanın garip şeylere gülebilme yeteneği, bu yönüyle onu, eylem olarak değilse bile düşünce olarak, diğerlerinin üzerine çıkaracak ve özgürlüğünü korumasını sağlayacaktır (Morreall, 1997: 142-143).

Mizah, insanlık tarihi kadar eski bir kavramdır. Bu nedenle ilk çağlardan beri insanlığın üzerinde en çok düşündüğü konulardan biri olagelmiştir. Antik düşünürler mizaha oldukça mesafeli yaklaşmışlardır. Mizah ve gülmenin değersiz ve bayağı olduğunu düşünmüşlerdir. Nitekim Platon, gülme esnasında kişinin mantıksal yetilerinin kontrolünü yitirdiğini ve gülme aracı olan alayın kişiyi zedelediğini düşünür (Usta, 2009: 26-27). Platon'un öğrencisi Aristoteles ise, gülmenin insanı baştan çıkartıp kaba saba ve bayağı kimselere dönüştürebileceğine dikkat çekmiştir. Dolayısıyla Aristoteles gülme konusunda Platon'un düşüncelerini izlemekle birlikte, insanın ne acı verici, ne de yıkıcı olan hata ve biçimsizliklere gülmesini sınırlandırmak istemiştir (Sanders, 2001: 126).

Mizah konusunda araştırmacıları en çok meşgul eden tartışma konularından biri de, mizaha yol açan nedenlerdir. Bu konu hakkındaki görüşler, kuramları doğurmuştur. Yeterlilikleri tartışmaya açık olsa da mizah hakkında ortaya birçok kuram atılmıştır. Bu kuramlar üç temel çerçevede geliştirilmiştir. Bu kuramlardan ilki üstünlük kuramıdır.Ingiliz filozof Thomas Hobbes tarafından geliştirilmiştir.Bu kurama göre mizah bir başkasının aşağılık durumuna karşı birebir üstünlük duygusu algılandığında ortaya çıkar (Bacaksız ve Oduncu, 2011: 957).Kuram, diğer insanların talihsizlikleri ve kusurları karşısında insanın kendini üstün hissetmesinden kaynaklanarak güldüğü iddiasındadır. Bir diğer kuram ise, uyuşmazlık (uyumsuzluk) kuramıdır. Kuram James Beattie tarafından sistemleştirilmiştir. Kuram temelinde zıtlık ve çatışma üzerine kurulmuştur. Uyumsuzluk kuramının ardındaki temel düşünce çok genel ve oldukça basittir. Nesneler, bu nesnelerin nitelikleri, olaylar, vs. arasındaki belirli kalıpların bulunmasını beklediğimiz düzenli 
yıllardan Meşrutiyet'e kadar olan dönemi kapsar. Divan edebiyatının en önemli hicviyelerinden biri, 15. yüzyıl şairlerinden Şeyhi'nin mesnevi biçiminde yazdığı "Har-nâme"dir. Edebiyatımızda mizah alanında yazılmış ilk örneklerden ve bu sahanın şaheseri kabul edilen Har-nâme, temiz bir Türkçe ve mizahi bir üslûpla yazıımasının yanı sıra sosyal tenkit içermesi yönüyle de son derece önemlidir (Özdemir, 2010: 70).

Cemal Kutay, Türk mizahında basının gelişim döneminden önce 1870'li yıllara kadar, göz ve kulak devrinin olduğundan bahsetmektedir (Kutay, 2013: 21). Osmanlı halkı, ilk kez Tanzimat döneminde bir mizah basınıyla karşılaşır. Meşrutiyetin ilanıyla birlikte siyasi olaylar ağırlık kazanmışır. Bir anlamda yazılı mizaha geçişi de belirleyen bu dönemde daha çok hicve yer verilmiştir (Karlıdağ, 2010: 304). Osmanlı yergi basınının tarihini iki devreye ayırmak gerekmektedir: İlk devre yergi basınının doğduğu yıllardır (1870-1877). İlk mizah dergisi Teodor Kasap tarafından 1870 yılında çıkarılan “Diyojen"dir. Diyojen, mizah basınının öncüsü olur ve onu 1871'de Hayal, 1872'de Çıngıraklı Tatar, 1873'de Latife ve Kamer, 1874'te Şafak ve Kahkaha, 1875'te Geveze ve Meddah, 1876'da Çaylak dergileri izlemiştir (Usta, 2009: 70). 1877-1878 Osmanlı-Rus savaşını bahane ederek Mebusan Meclisi'ni kapatan Abdülhamid, otuz iki yıl mutlak yönetim sürmüş ve Batı örneği mizah dergilerinin basımını yasaklamıştır (Öngören, 1998: 61). Bu dönemde yergi basını yurt dışına sığınmış ve ülkeye gizli yollardan sokulmuştur. Osmanlı yergi basınının ikinci devresi 1908 Jön Türk devrimi ve sonrasındaki yergi basınının hızı gelişim dönemini içerir (Georgeon, 1996: 47). 1908 yılı, mizahımız için bir dönüm noktası sayııır. Bu dönemde Batıı anlamda mizah dergileri birbiri ardına yayınlanmıştır. Buna karşılık geleneksel Osmanlı mizah örnekleri yok olmaya başlamıştır.

Birinci Dünya Savaşı'ndan sonra mizah basınına, Ankara ve İstanbul hükümetlerinin yönettiği dergiler egemen olmuştur.Sedat Semavinin çıkardığı "Güleryüz" Ankara hükümetini, Refik Halit Karay'ın çıkardığı "Aydede" ise İstanbul hükümetini desteklemektedir. Aydede dergisi, Kurtuluş Savaşı'na karşı olan, Yunan'ı tutan, Atatürk'e saldıran, Kuvay-i Milliye'yi halk gözünden düşürmeye uğraşan bir tutum içerisindedir. Güleryüz ise Kurtuluş Savaşı'nı açıkça destekleyen bir mizah dergisidir. Bu iki zıt kanat arasında çatışma, elbette kaçınılmazdır. Kurtuluş Savaşı kazanılınca Aydede kapanır, ancak Refik Halit'in yurt dışına kaçması sonucu geriye kalan kadro yeni bir dergi yayımlamaya başlar. Bu dergi 1978 yılına kadar yayını sürdürecek ve bu dönemde oldukça etkili olacak Akbaba dergisidir (Öngören, 1998: 68-71).

Kurtuluş Savaşı sonrasında, Cumhuriyet Dönemi mizahının ilk biçimlenişi ortaya çıkmıştır. 1923'ten sonra birçok tarih ve gün, Cumhuriyet Dönemi mizahı için önemli olmaya başlayacaktır. Fakat dönüm noktası olabilecek tarih, 3 Kasım 1928'de Latin alfabesinin kabul edilmesidir. 1928'den öncesi ve sonrası şeklinde bir ayırım yazılı Cumhuriyet mizahı için ayrı bir geçerlilik taşıyacaktır. 1928 yılı hem büyük bir bitişi, hem de yeni bir başlangıcı işaret ettiğinden, Cumhuriyet Dönemi mizahı için önemli bir evre; ayrıca önemli dönemeç noktası olur (Öngören, 1998: 73). Cumhuriyet mizahının ilk dönemi tam bir durgunluk dönemidir. Bu durgunluğun iki nedeni vardır. Bunlardan ilki; harf devrimiyle beraber okuma-yazma oranının sıfırlanmasıdır. Bu büyük devrim, kültür hayatını bütünüyle değiştirmiştir. Bu devrim sonucunda, gazete ve dergiler kapanma tehlikesiyle karşı karşıya kalmışlardır (Usta, 2009: 77). Halk eğitimi olabildiğince hızlı gerçekleştirse de yayın sayısı ilk beş yılda az sayıdadır (Yılmazoğlu, 2012). Durgunluk döneminin ikinci nedeni ise; Kurtuluş Savaşından yeni çıkan bir milletin Cumhuriyetin kurucularına olan saygısıdır. Türk halkı Birinci Dünya Savaşı'nda ve ondan hemen sonraki Ulusal Kurtuluş Savaşı'nda aktif olarak savaşmıştır. Bu durumda, halk mizahı ve halktan yana mizah olanaksızdır. Çünkü mizah, başkaldıramaz durumdaki halkların silahıdır. Savaşacak gücü olmayan milletler, mizah silahını kullanarak iktidarı devirmeye çalışırlar. Halkın başkaldırdığı, savaşın içinde bulunduğu, savaşa 
katıldığı durumlardaysa mizahın yeri yoktur (Nesin, 1973: 44). Cumhuriyetle birlikte bir kuruculuk ve ülkücülük dönemi bunun arkasından da bir çöküntü ve bunalım dönemi gelmiştir. Türkiye, II. Dünya Savaşı'na girmediği halde, büyük bir ekonomik ve sosyal çöküntüye uğramıştır. Savaşın getirdiği olumsuz sonuçlar mizahı beslemiştir.

İkinci Dünya Savaşı sonunda Cumhuriyet kesin olarak çok partili hayata doğru yönelmiş ve bu gelişme bütün kurumlarda ve düşünce alanlarında geniş değişmelere yol açmıştır. Bu gelişmeden en çok yararlananlardan biri de mizah olmuştur. Demokratik ortamda Cumhuriyet mizahı, hem eserlerin olgunluğu, hem de kadrosunun zenginliği yönünden, övünülecek bir düzeye çıkmıştır (Öngören, 1998: 68-71). 25 Kasım 1946'daMarkopaşa dergisinin ilk sayısı çıkmıştır. Markopaşa dergisi, karikatür tarihimizde en özel yere sahip yayınlardan birisidir. Bir deyişle, yıllardır mizahın keskin tarafını adeta kış uykusuna yatıran, yeni kurulan rejimin bekası için eleştirilerini dile getirmeyen veya getiremeyen mizahçıların bir anlamda patlamasıdır (Özocak, 2011: 269-270). Markopaşa, Türk mizahında daha önce rastlanmamış bir diklikte, iktidarın yani Cumhuriyet Halk Partisi'nin karşısında durur ve 1950 yılında Demokrat Parti'nin başa geçmesinde büyük bir paya sahip olur (Usta, 2009: 78). Dergi, altmış bin civarında bir satış rakamına ulaşarak büyük ses getirmiştir. Sık sık kapatılmış ve baskılar nedeniyle durmaksızın isim değiştirmek zorunda kalmıştır. Demokrat Parti iktidarı 27 Mayıs 1960 yılında askeri darbeyle yıkılınca, ülkede yeni Anayasa ile hürriyet rüzgârları esmeye başlar. Ancak mizah basını bu özgür dönemde durgunluk yaşamıştır.

1970'li yıllarda kırsal kesimden büyük kentlere doğru yoğun göçler yaşanmıştır. Kırsal kesimden gelen milyonluk kitleler kent alanlarına yerleşmede güçlükler yaşamış ve alternatif bir İstanbul yaşantısı oluşturmuşlardır. 1970'ler mizahının ana kaynağını kırdan kente göç eden kitlenin yaşadığı sorunlar oluşturmuştur. Halkın mizahı da buradan doğmuştur. Gırgır dergisi böyle bir dönemde ortaya çıkmıştır. 26 Ağustos 1972'de Gırgır dergisi Oğuz Aral'ın yönetiminde yayın hayatına başlamıştır.

Gırgır dergisi politik konuları biraz daha geri plana atarak, halkın yoksulluğu, hayat pahalıığı gibi sosyal ve ekonomik konulara ağırlık vermiş ve geniş bir kitleye seslenme olanağı bulmuştur. Gırgır, kendinden önceki mizah geleneğini yıkarak yeni bir gelenek yaratmıştır (Özocak, 2011: 272). Bu tarihten sonra Gırgır dergisi getirmiş olduğu birçok yenilikle karikatür tarihimize damga vurmuştur.

12 Eylül 1980 askeri darbesi bütün ülkede büyük bir değişikliğe neden olmuştur. 1980 darbesinin ilk yıllarında Türkiye'de karikatür çizilemez, mizah yapılamaz olmuştur. Bu dönemde Gırgır beş hafta boyunca kapatma cezası alır. Sonraki üç yıl içerisinde mevcut baskılardan ötürü muhalefet yapılamaz olmuştur. Bu üç yıllık dönemde muhalefet yapamayan Gırgır dergisinin bütün imajı silinmiştir (Usta, 2009: 79). 12 Eylül 1980 harekâtı ile Türkiye'de CHP dâhil bütün partiler ve dernekler kapatılmıştır. Siyasi partilerin yanı sıra, 1970 yılında açılan Karikatürcüler Derneği ve Karikatür Müzesi de kapatılmıştır. Buna ek olarak Karikatürcüler Derneğinin düzenlediği Uluslararası Nasreddin Hoca Yarışması 1987 yılına kadar yapılamamışıı. Bunun üzerine dünya karikatürcüleri 12 Eylül yöneticilerine karşı büyük tepki göstermiştir (Öngören, 1998: 107).

1980 sonrası neo-liberal politikalarla birlikte ekonomide ve toplumda yaşanan değişikliklerin mizaha yansımasıyla karakterler ve sorunlar değişmiştir.12 Eylül darbesiyle susan mizah basını, 6 Kasım 1983 genel seçimlerinden sonra yeni bir başlangıç yapar. 1983 yılından sonra mizahçıların baş konusu Turgut Özal olmuştur. 1990'lı yıllarla beraber ülkenin bir "medya çağı"na girmesiyle birlikte, özelleştirmelerin artması, kuzeyde Sovyetler Birliği'nin çöküşüyle dünyanın tek kutuplu hale gelmesi, bununla beraber dünyada bir savaşlar döneminin başlaması, Türkiye'de gün geçtikçe 
kendini daha fazla hissettiren hayat pahalıı̆̆ı, genç kuşakların giyim kuşamlarından, dinledikleri müziklere kadar yaşadığı dönüşüm ve kültürel hayattaki dejenerasyon, mizah dünyasına da yansımış ve karikatür dergiciliğinde bir devrin kapanarak bir başka devrin açıımasını sağlamıştır (Özocak, 2011: 277).

2000'li yıllara doğru Türkiye'de mizahçılar yeni konularla ilgilenmek zorunda kalmışlardır. Çeteler, mafyalar, kaçakçılar, kasetler, tetikçiler, özelleştirmeler, terör olayları bu dönemin mizah gündemini oluşturur. Zincirleme olaylar karşısında toplum şoklarla sarsılmıştır. Liberal anlayışın ve kamplaşmanın sonucu gazeteler ve TV kanalları, çalışanlarıyla birlikte alınır satıı olmuştur. Bütün bu özellikler, 2000'li yıllarda mizahın ve karikatürün büyük yapı değişikliğine uğramasına neden olmuştur (Öngören, 1998: 111-112). Günümüzde, Türkiye'de bazı mizah dergilerine siyasi otoriteler tarafından davalar açılmıştır. Ancak mizah yine geri adım atmayarak açılan davalara veya kapatma baskılarına rağmen açık sözlülükle ve sert bir şekilde eleştirilerine devam etmektedir. Hatta daha ileri giderek açılan davalar ile de dalga geçmeyi başarmaktadır.

1990'ların ikinci yarısından itibaren internet tüm dünyada olduğu gibi Türkiye'de de yayılmaya başlamıştır. İnternet teknolojisi sayesinde yeni medyanın yaygınlaşmasıyla birlikte, yeni mizah türleri ortaya çıkmaya başlamıştır. İnternetle birlikte oluşan yeni medyanın mizahı nasıl etkilediğini daha iyi anlayabilmek için öncelikle yeni medya kavramına bakmamız gerekmektedir.

\section{Yeni Medya ve Mizah}

İnternetin gelişi ve yaygınlaşması ile birlikte geleneksel medyanın tek yönlü iletişim akışına dayalı sistemi yavaş yavaş değişmeye başlamış, en önemli değişim de yeni medyanın ve sosyal medyanın gelişimi olmuştur. Yeni medya bireysel kullanıma açıklığı ile,interaktiviteye olanak tanıması ile, istenilen bilgiye çok kısa sürede ulaşılan bir ortam olması ile, bireylerin birbirleri ile kolayca haberleşmesini sağlaması ile ve bireysel tercihlere, seçimlere açıklığı ile giderek küreselleşmiş bulunan dünyanın ilgi ve merak odağı olmuştur. Yeni medyanın ve sosyal medyanın geleneksel medyadan ayrılan çok sayıda yanı vardır. Bu özellikleri geleneksel medya ile yeni medyayı yakınsama sürecine sokmuştur çünkü geleneksel medyanın birçok özelliği tartışılmaya başlanmıştır. Yeni medyanın bireysel yayıncılığı olanaklı kılması, alternatif medyayı geliştirmesi, basıma dayalı yayıncıığın sınırılıklarını ortadan kaldırması, yurttaş gazeteciliğini geliştirirken profesyonelliği ikinci plana düşürmesi, ucuz, kolay ve çok hızlı bir yayıncılık dünyasına kapıları açması vb. çok sayıdaki özelliği onu geleneksel medya karşısında çok güçlü bir yere taşımışıı.

Yeni medya kavramı 1970'lerde, bilgi ve iletişim tabanlı araştırmalarda, sosyal, psikolojik, ekonomik, politik ve kültürel çalışmalar yapan araştırmacılar tarafından ortaya atıımış bir kavramdır. Ancak 1970'lerde değinilen anlam, 1990'larda müthiş bir ivme kazanan bilgisayar ve internet teknolojisi ile birlikte genişlemiş ve farklı boyutlara ulaşmıştır. Bazı yazarlar ve araştırmacılar yeni medyayı bir teknoloji listesi ile gayet basit bir düzenleme biçiminde açıklamışlar ve CD-ROM, HTML, akan ortam, sayısal video düzenleme, ağ uygulamaları, DVD video, multimedya gibi ortamlara yeni medya demişlerdir. Her ne kadar bu tespit çok yanlış olarak gözükmese de biraz kısıtlı ve eksik görünmektedir. Böylesi bir durumda her geçen sene içerisinde gelişme gösteren bu teknolojilere yeni bir tanımlama getirmek gerekecektir. Yeni medyayı "yeni" yapan temel prensipleri ve özellikleri gözden geçirmek gereklidir (Dilmen, 2007: 114).

Richard Rogers'a göre, yeni medyanın bazı temel özellikleri şunlardır:

- Etkileşim (Interaction): İletişim sürecinde etkileşimin varlığına gerek duyulmaktadır. Bu sayede hem alıcı hem de verici birbirinden etkilenmektedir. 
karakterinin mahalleden arkadaşı olan bir karakterdir. Bahattin'in serseri bir tipi vardır. Kulak arkasında sigarayla dolaşır. Yetişkin erkek ayakkabısı giyer, öyle ki ayakkabıları bedeninden büyüktür. Fırat'ı sigaraya alıştırma girişimleri olmuştur. Bazı bölümlerde bir iş yerinde çalışığı görülmektedir. Mahallesinde lakabı "Sümüklü Bahattin"dir. Abisinin askerden taramalı tüfek getirmesi ve âşık olduğu kızı kaçırmak en büyük hayallerindendir (Ray, 2013).

Uykusuz dergisinde sıradan bir karakter olan Bahattin, yeni medya ve özellikle sosyal medyanın etkisi ile ilginç bir örnek olarak ortaya çıkmıştır. Daha önceden var olan çizimi yeni bir mizahi forma dönüştürülerek, tek başına bir karakter halini almıştır.

Sosyal medyanın yeni "fenomeni", "trendi”, "ikonu"; konunun asıl kahramanı olan Fırat'ı gölgede bırakmıştır. Hemen herkes onu "Pıçakçı Bahattin" olarak tanımaktadır. Sosyal medyada ele alınma biçimi ile gerçek Bahattin karakterinin içi boşaltılmıştır. "Ülkücü Bahattin”, "Konyalı Bahattin", "Bolulu Bahattin", "Pıçakçı Bahattin”, "Filmci Bahattin", "Laz Bahattin", "Fizyoterapist Bahattin", "Galatasaraylı Bahattin" gibi onlarca kimlikle birlikte anılır olmuştur (Ray, 2013). Günümüzde herkes Bahattin'i kendi çevresine çekmektedir. Oluşturulan balon esprilerde yöresel ağızlarda kullanılmaktadır. Bolu Gündem gazetesinde 23 Kasım 2013 tarihinde bu konuyla ilgili yer alan bir habere göre:

"Bahattin'in Bolu şivesi ile yaptığı espriler takipçileri tarafından beğeni kazandı. 'Bolulu Baattin derle bana mertliğin peşindeyim sloganı', sosyal paylaşım sitelerinde adına sayfa açılan Bahattin'in şimdiden 2 bin 61 beğenicisi var. Orijinal paylaşımların dışında birçok kişi de Bahattin karakteri üzerinden kendi fikirlerini kitleler ile paylaşıyor." (Bolu Gündem, 2013).

Resim 1. Bahattin Karakteri

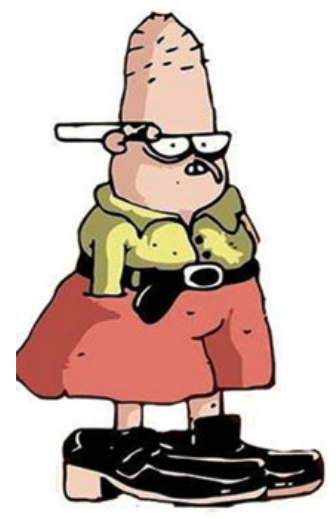

Kaynak: http://www.neyebaksam.com/vkq1P(23.04.2014).

Bahattin karakterinin yaratıcısı Uğur Gürsoy, kendisiyle yapılan bir röportajda şunları söylemektedir:

"Sosyal paylaşım sitelerinde dolaşan Bahattin esprilerinin benimle hiçbir ilgisi yok. Uykusuz dergisini takip edenler, Fırat'ın yan karakteri olduğunu bilir. Esas karakter Fırat'tı ve ilk çıktığında deli gibi bir tipti. Hayal görürdü. Sonra Bahattin gibi daha ilginç yan karakterler çıktı. Fırat'ı kadınlar, Bahattin'i erkekler daha çok seviyordu. Bahattin mahalledeki korkulan, sinirli çocuktu. Bahattin, çocukluğumuzun geçtiği mahalleden biriydi. O da sigara içen, simit satan, bir yandan okuyan, kafası çok çalışan bir çocuktu. 
Uğur Gürsoy, sosyal medyada sıkça paylaşılan Uykusuz dergisi için çizdiği "Bahattin" karakteri için Türk Patent Enstitüsüne başvurarak Bahattin'i markalaştırmak istemiştir. Başvuru "basın yayın", "eğitim hizmetleri ve matbaacılık hizmetleri" sınıflarında yapıımıştır (Cumhuriyet, 2014). Uğur Gürsoy'un kaleminden çıkan, sosyal medyanın fenomeni Bahattin'in son zamanlarda televizyon dizisi olması gündeme gelmiştir. Ancak balon esprilerini hikâyeye yansıtmanın sorun olması nedeniyle proje ertelenmiştir (http://www.acunn.com/haber/baattin-in-dizisi-direktendondu/142458).

Sosyal paylaşım sitelerinde yoğun olarak paylaşılan Bahattin, Akit Gazetesi'nin Facebook sayfasında yayınlanan bir yazıyla ilginç bir şekilde eleştirilmiştir. Konuyla ilgili eleştiri Mehmet Nebioğlu'nun "Bahattin'in Gerçek Yüzü" başlıklı yazısıdır. Nebioğlu yazısında, Bahattin karakterinin kulağında taşıdığı sigarasını ve bıçaklarım anlamına gelen "pıçaklarım" kelimesini kullanmasını eleştirmiştir. Ayrıca Bahattin'in yüz hatlarının çizimi nedeniyle cinsellik yönünün de olduğunu belirterek, Bahattin adının "Dinin güzelliği" anlamına gelen İslami bir ad olduğunu söylemiştir. Bahattin'in subliminal mesaj içerikli olduğunu da iddia ederek, dinin güzelliği anlamına gelen Bahattin isminin taşıdığı anlama tezat ahlaki olmayan söz ve davranışlar barındırmasını eleştirmiştir (http://www.odatv.com/n.php?n=bahattin-bu-yaziyi-okusa-picaklarimderdi-0411131200). Mehmet Nebioğlu'nun yazısı kamuoyunda oldukça yankı bulmuş ve internet üzerinde yaygın bir tartışma formu olan sözlüklerde konu tartışılmıştır. Sözlüklerde konuyla ilgili değerlendirmeler incelendiğinde, argo ve küfür kullanımının yaygın olduğu görülür. Özellikle kişilik haklarına ciddi zarar verici ifadelere rastlanmaktadır.

İnternet üzerinden birçok sosyal paylaşım sitesi incelendiğinde Bahattin'in güncel sorunlarla ve toplumda bozuk işleyen düzenle ilgili balon esprilerde yaptığı görülmektedir. Bu konuyla ilgili, Zonguldak'ta yerel yayıncılık yapan Pusula gazetesinin "Baattin Zonguldak'ın hangi önemli sorununa el attı?" başlıklı yazısında şehirde hızla kurulan termik santrallere karşı bir eleştiri getirilmeye çalışılmıştır. Haberde yer alan karikatür şu şekildedir:

Resim 2. Baattin Zonguldak'ın hangi önemli sorununa el attı?



Kaynak:http://www.pusulagazetesi.com.tr/haber.php?hayns=2\&yazilim= haberler\&osmanli=hdetay\&aid=36859\&titlem=36859 (26.11.2013). 
Bahattin örneğinde görüldüğü üzere yeni medya, geleneksel ürünlerin küresel taşıyıcısı olarak, yeni formların ve konuların ortaya çıkmasını sağlamaktadır. Ancak bunu yaparken kültürün bütün formlarını deformasyona da uğratabilmekte, onları kendi tarihlerinden kopartıp tanınmaz hale getirebilmektedir. Bu dönüştürme sürecinde kültür ürünleri şiddet eğilimlerinin malzemesi olabilmekte, kimin yaptığı belli olmayan çarpıtmalara da uğrayabilmektedir. İnternet üzerinde çok sayıda sosyal paylaşım sitesi incelendiğinde Bahattin karakterinin birçok örnekte şiddet malzemesi olarak kullanıldığı görülmektedir. Bazı örneklerde kişilerin ya da kurumların haklarına zarar verici yorumlarda bulunulduğu tespit edilmiştir. En önemlisi de bu eylemleri gerçekleştiren kişilerin tespit edilememesidir. Ancak bu yazı alanları toplumsal ve sistemsel işleyişe karşı, mevcut iktidara karşı sosyal bir eleştiri imkânı da sunmaktadır. Birçok örnekte Bahattin karakteri üzerinden eleştiri yapılmıştır. Bir bakıma seslerini duyuramayan, dikkate alınmayan kitleler Bahattin karakteri üzerinden seslerini duyurmaya çalışmışlardır. Geleneksel medya ürünlerinde içerik-tüketicisi olarak yer alan kitleler, yeni medya sayesinde içeriğe müdahale edebilir ve gündemi belirleyebilir hale gelmişler ve üretici bir rol oynamaya başlamışlardır. Sosyal medyada yer alan birçok Bahattin örneği bu tespiti doğrular niteliktedir.

Ancak bu örnekte görüldüğ̈ gibi yeni medya ve sosyal medya, kullanıcılarını hem tüketici ve hem de üretici olarak konumlandırırken, var olan dengeleri olumlu ya da olumsuz anlamda yerinden oynatabilmektedir. Bu nedenle yeni medyayı ve sosyal medyayı getirdiği olanaklar açısından olduğu kadar yarattığı riskler açısından da değerlendirmek gerekmektedir. Yani tek yönlü değerlendirmeler sosyal medyayı anlamamız için yetersiz kalabilirler. Örnek olarak incelediğimiz mizahi Bahattin karakteri, yaratıcısının denetiminden çıkmış, topluma malolmuş, ancak aynı zamanda küfür, argo ve hakarete dayalı bir söylemin odak noktası, icra alanı olmuştur.

\section{Sonuc,}

Mizahın kavramsal boyutuyla birlikte ele alınması tanımların sınıflandırılmasıyla ilgili birtakım sorunları beraberinde getirmektedir. Mizah üzerine yapılan tanımların kısıtııığı, genel anlamda herkesin kabul ettiği ortak bir tanımın yapılamadığını göstermektedir. Mizahın karmaşık bir kavram olması, sınıflandırımasını zorlaştırmaktadır. Mizah konusunda araştırmacıları en çok meşgul eden tartışma konularından biri de, mizaha yol açan nedenlerdir. Bu konu hakkındaki görüşler, kuramları doğurmuştur. Yeterlilikleri tartışmaya açık olsa da mizah hakkında ortaya birçok kuram atımıştır. Bu kuramlar sırasıyla: Üstünlük kuramı, Uyuşmazlık (uyumsuzluk) kuramı ve Rahatlama kuramıdır. Ancak bu kuramlar, mizaha neden olan tüm durumları açıklayamaması bakımından sorunludur. Mizaha neden olan tüm durumları içerisine alan bir kuramın geliştirilememesi tartışma konusu olmuştur. Mizah, yokluğunda çok büyük bir boşluğun oluşacağı bir yetenektir, bir potansiyeldir, bir zekilik biçimi ve ince duyudur. Çünkü insanların eleştiri yapma, bir konu hakkında korkmadan, çekinmeden düşündüklerini dile getirme, devleti yönetenlere karşı durabilme ve hakkını açık yüreklilikle savunabilme konusunda her zaman bir çekinceleri olmuştur. İnsan mevcut otoritelere karşı ancak mizah yaparak direnebilmekte ve var olan otoriteleri eleştirebilmektedir. Bu nedenle tarih boyunca iktidarlar mizahtan korkmuş ve onu denetim altına almaya çalışmışlardır.

Türk mizahı içinde bulunduğu döneme, topluma, kültüre ve teknolojiye göre değişiklik göstermiştir. İlk değişiklik, Türklerin Uzak Asya'dan Anadolu'ya gelme sürecinde yaşanmıştır. Bu süreçte, göçebe kültürden yerleşik kültüre geçilmiştir. Bu önemli değişiklik mizahı da doğrudan etkilemiştir. Daha sonra yaşanan en önemli değişiklik, sözlü mizahtan yazılı mizaha geçerken yaşanmıştır. Matbaanın yaygınlaşmasıyla birlikte Batılı anlamda mizah dergileri ortaya çıkmıştır. 
Bu dönemden sonra geleneksel mizah türleri yok olma aşamasına gelmiştir. Antik Anadolu'dan günümüze kadar bu topraklarda yaşayan her kültürün üzerine bir şeyler koyarak geliştirdiği mizah, bu uzun yolculuğu sırasında birçok değişiklik göstermiştir. Genel anlamda, Türk mizahını dönemsel olarak üç gruba ayırabilmekteyiz. Bu üç grup sırasıyla; Selçuklular Dönemi, Osmanlılar Dönemi ve Cumhuriyet Dönemi'dir. Her dönemin kendi içerisinde belirgin özellikleri ve kırılma noktaları vardır.1990'ı yıllarla birlikte Türkiye "yeni medya çağı"na girmeye başlamış, bu dönem ekonomiden sanata kadar birçok alanı derinden etkilemiştir. Kitle iletişim araçlarında yaşanan gelişmeler toplumda büyük dönüşümlere yol açarak mizahı şekillendirmiştir. 1990'ların ikinci yarısından itibaren yeni medya ve sosyal medya teknolojileri tüm dünyada olduğu gibi Türkiye'de de yayılmaya başlamıştır. Geleneksel medyada izleyici konumunda bulunan insanlar, yeni medya ile birlikte içeriğe müdahale edebilir duruma gelmişlerdir. Yeni medyada varlığını sürdüren fotoğraflar günümüzde bazı değişimlere uğrayarak yeni formlara dönüşmeye başlamıştır. Bu yeni formlara Türkiye'den verilebilecek en iyi örnek Bahattin örneğidir.

Bahattin Uykusuz dergisinde bir yan karakter iken, yeni bir form örneği olarak sosyal medyada fenomen olmuştur. İnsanların Bahattin karakterini bu kadar çok sevmesinin nedeni, gerçek hayatta karşımıza çıkan bir karakter olmasıdır. Buna ek olarak balon esprilerle kullanıcıların içeriğe müdahale edebilmeleridir. Sosyal paylaşım adresleri incelendiğinde Bahattin adına açılmış birçok hesabın olduğu görülmektedir. Bu hesaplar çok çeşitli olup etnik unsurlar içermektedir. Bu etnik unsurlar kendi yerel şiveleriyle balon esprilere yön vermektedir. Bahattin karakteri sosyal medya üzerinden incelendiğinde birçok olumsuz ifade ile de karşı karşıya kalınmaktadır. İnsanlar Bahattin karakteri üzerinden söylemler geliştirerek gerçeği çarpıtmaktadırlar. Söylemler genellikle küfür, argo ve olumsuz davranışlar içermektedir. Bahattin karakteri üzerine birçok eleştiri yapılmıştır. Eleştiriler karakterin çok sığ düşünceler içerdiğine yöneliktir. Ancak sosyal paylaşım adreslerine ve diğer yazılara bakıldığında Bahattin'in toplumda bozuk işleyen düzene karşı sosyal bir eleştiri yöntemi olarak kullanıldığı da göze çarpmaktadır. Bu yönü karakterin sığ olmadığı, aksine güçıü bir eleştiri yöntemi olarak kullanıldığını göstermektedir. Yine Bahattin karakterinin çok popüler olması ticari anlamda yaratıcısına gelir kaynağı olmaktadır. Bu örnekte de görüldüğü gibi yeni medya yeni türler üretmekle birlikte yeni sektörler de oluşturmaktadır. Ancak tüm bu süreçler olumlu gibi görünmesine rağmen aynı zamanda olumsuz birçok niteliği de bünyelerinde taşımaktadırlar. Bu nedenle süreç tek yönlü değil çoklu bakış açıları ile değerlendirilmeli, interaktiviteyi beslerken birçok deformasyona yol açtıkları da göz önüne alınmalıdır. 


\section{KAYNAKC A}

Avcı, Artun (2003). "Toplumsal Eleştiri Söylemi Olarak Mizah ve Gülmece” Birikim Dergisi. Sayı 166: 80-96.

Çakır, Mukadder (2013) "Sosyal Medya ve Gösteri” (11-68) Ali Büyükaslan, Ali Murat Kırık (Ed.) Sosyalleşen Birey, Sosyal Medya Araştırmaları, Konya: Çizgi.

Dikmen, Mehmet (2002). Osmanlıca-Türkçe Sözlük. İstanbul: Cihan Yayınları.

Dilmen, Necmi Emel (2007). "Yeni Medya Çerçevesinde İnternet Günlükleri-Bloglar ve Gazeteciliğe Yansımaları", Marmara İletişim Dergisi. Sayı 12: 114.

Georgeon, François (2007). “Osmanlı İmparatorluğu'nda Gülmek mi?”, Doğu'da Mizah. Çev: Ali Berktay, İstanbul: Yapı Kredi.

Georgeon, François (1996). “İstanbul'un Aynası Osmanlı Yergi Basını”, Çev: M. Emin Özcan, Gül Diken Mizah Kültürü Dergisi. Sayı 10: 47.

Geray, Haluk (2003). İletişim ve Teknoloji Uluslararası Birikim Düzeninde Yeni Medya Politikaları. Ankara: Ütopya.

Karlıdağ, Serpil (2010). "Sayısal Çağda Mizah: İnternet Güldürüyor mu?”, Ulusal İletişim Kongresi Gülmenin Arkeolojisi ve Medyada Mizah Olgusu Bildiriler Kitabı,Erzurum: Mega Ofset, 13-15 Mayıs 2010: 304.

Kırık, Ali Murat (2010). Etkileşimli Televizyon. İstanbul: Anahtar Kitaplar.

Kurt, Murat (2011). Miracle Picture Dictionary. İstanbul: MK Publications.

Kutay, Cemal (2013). Osmanlı'da Mizah. İstanbul: Acar Bilgi Merkezi.

Morreall, John (1997). Gülmeyi Ciddiye Almak. Çev: Kubilay Aysevener ve Şenay Soyer, İstanbul: İris.

Nesin, Aziz(1973). Cumhuriyet Döneminde Türk Mizahı. İstanbul: Akbaba.

Oskay, Ünsal (2000). Tek Kişilik Haçlı Seferleri. İstanbul: İnkılap Kitapevi.

Öngören, Ferit (1998). Cumhuriyet'in 75. Yılında Türk Mizahı ve Hicvi. İstanbul: Türkiye İş Bankası Kültür.

Özdemir, Mehmet (2010). "Har-nâme'nin Tahkiye Dışındaki Bölümlerine Şekil ve Muhteva Açısından Bakış", Uşak Üniversitesi Sosyal Bilimler Dergisi. Sayı 5: 70.

Özocak, Gürkan (2011). "Türkiye'de Siyasi İktidarın Mizahla İmtihanı: İfade Özgürlüğü ve Karikatür”, TBB Dergisi, Sayı 94: 260-294.

Özyılmazel, Ayşe (2013) “Adamım Baattin!”, Sabah. 19.11.2013.

Ray, Hasan (2013). "Türkiye'de Mizah Kültürünün Gelişimi ve Bahattin”.http://www.politikadergisi.com/okurmakale/turkiyede-mizah-kulturunun-gelisimi-ve-baattin.Erişim Tarihi: 23.04.2014.

Sanders, Barry (2001). Kahkahanın Zaferi. Çev: Kemal Atakay, İstanbul: Ayrıntı. 
Usta, Çiğdem (2009). Mizah Dilinin Gizemi. Ankara: Akçağ.

Yengin Ateş, Sibel (2013). “Bana Bahattin’i Sormayın!”, Akşam. 15.12.2013.

Yılmazoğlu, Emre (2012). "Türkiye'de Mizah Yayıncılığının Kısa Tarihi”, Gündoğuşu Dergisi. Sayı 5.

"Baattin Marka Oluyor" (2014). Cumhuriyet. 26.03.2014.

"Baattin Patlaması" (2013). Milliyet. 09.11.2013.

"Bolulu Baattin Fenomen Oldu" (2013). Bolu Gündem. 23.11.2013.

"Bahattin bu yazıyı okusa 'pıçaklarım' derdi” (2013). http://www.odatv.com/n.php?n=bahattin-bu-yaziyi-okusapicaklarim-derdi-0411131200 Erişim Tarihi: 26.05.2014.

"Bahattin dizi mi oluyor?", (2014). http://www.acunn.com/haber/baattin-in-dizisi-direkten-dondu/142458.Erişim Tarihi: 26.04.2014.

Bahattin Resmi (2014).http://www.neyebaksam.com/vkq1P.Erişim Tarihi: 23.04.2014.

"Baattin Zonguldak'ın hangi önemli sorununa el attı?" (2013). http://www.pusulagazetesi.com.tr/haber.php?hay ns=2\&yazilim=haberler\&osmanli=hdetay\&aid=36859\&titlem=36859. Erişim Tarihi: 02.07.2014.

Ekşi Sözlük (2014). https://eksisozluk.com/pic-bahattin--2125302. Erişim Tarihi: 26.04.2014.

Facebook (2014). https://www.facebook.com/Picbaattinn. 26.04.2014.

“Gülmece”, Türk Dil Kurumu (2014). http://www.tdk.gov.tr/index.php?option. Erişim Tarihi: 24.04.2014.

“Mizah”, Türk Dil Kurumu (2014). http://www.tdk.gov.tr/index.php?option. Erişim Tarihi: 24.04.2014. 